\title{
Long-Term Effects of
} $S(+) \mathrm{N}-n$-Propylnorapomorphine Compared with Typical and Atypical Antipsychotics: Differential Increases of Cerebrocortical $\mathrm{D}_{2}$-Like and Striatolimbic $\mathrm{D}_{4}$-Like Dopamine Receptors

Frank I. Tarazi, Ph.D., Sylva K. Yeghiayan, Ph.D., Ross J. Baldessarini, M.D., Nora S. Kula, M.S., and John L. Neumeyer, Ph.D.

Changes in $D_{2}$-like dopamine ( $D A$ ) receptor binding in rat brain regions were compared by quantitative in vitro receptor autoradiography after 21-d treatment with a typical (fluphenazine), atypical (clozapine), or candidate atypical antipsychotic $(S[+]-N-n$-propylnorapomorphine, $[+]-N P A)$. Fluphenazine treatment significantly increased binding of the $D_{2,3,4}$ radioligands $\left[{ }^{3} H\right]$ nemonapride and $\left[{ }^{3} \mathrm{H}\right]$ spiperone in caudate-putamen (CPu: $\left.22 \%, 32 \%\right)$, nucleus accumbens (ACC: $67 \%, 52 \%$ ), olfactory tubercle (OT: $53 \%, 43 \%$ ), and medial prefrontal cerebral cortex (MPC: $46 \%, 47 \%$ ) but not dorsolateral frontal cortex (DFC). $D_{2}$-like binding in MPC was also increased by (+)-NPA $(49 \%, 39 \%)$ and clozapine $(60 \%, 40 \%)$, but not in DFC, CPu, ACC, or OT. Binding of $D_{2,3}$-selective $\left[{ }^{3} \mathrm{H}\right]$ raclopride increased less after fluphenazine in ACC $(27 \%)$ and $\mathrm{CPu}(16 \%)$ than with the nonselective radioligands, and not after clozapine or (+)-NPA. $D_{3}$-selective binding of $\left[{ }^{3} \mathrm{H}\right] \mathrm{R}(+)-7-\mathrm{OH}-\mathrm{DPAT}$ was not changed with any treatment or region including islands of Calleja. Binding of $\left[{ }^{3} \mathrm{H}\right]$ nemonapride or $\left[{ }^{3} \mathrm{H}\right]$ spiperone under $\mathrm{D}_{4}$-selective conditions (with $300 \mathrm{nM} S[-]$-raclopride and other masking agents, at sites occluded by $D_{4}$ ligand L-745,870), was increased by fluphenazine, (+)-NPA, clozapine in ACC $(120 \%, 76 \%, 70 \%$, respectively), and CPu $(54 \%, 37 \%, 35 \%)$, but not in OT, DFC or MPC. These results support the hypothesis that cerebrocortical $D_{2}$-like and striatolimbic $D_{4}$-like receptors contribute to antipsychotic actions of both typical and atypical drugs and encourage further consideration of $S(+)$ aporphines as potential atypical antipsychotics.

[Neuropsychopharmacology 17:186-196, 1997] (C) 1997 American College of Neuropsychopharmacology. Published by Elsevier Science Inc.
From the Consolidated Department of Psychiatry and Neuroscience Program, Harvard Medical School, Boston, MA; the Mailman Research Center (FIT, SKY, RJB, NSK); the Alcohol and Drug Addiction Research Center (JLN), McLean Division of Massachusetts General Hospital, Belmont, MA; and the Bouvé College of Pharmacy and Allied Health Professions, Northeastern University, Boston, MA, USA (JLN).

Address correspondence to: Dr. Frank I. Tarazi, Mailman Research Center, McLean Hospital, Harvard Medical School, 115 Mill St., Belmont, MA 02178.

Received July 9, 1996; revised February 27, 1997; accepted March $14,1997$.
KEY WORDS: Aporphines; Antipsychotics; Autoradiography; Brain; Clozapine; Dopamine receptors; Fluphenazine; Nemonapride; $S[+]-N$-n-propylnorapomorphine; Spiperone

Dopamine (DA) interacts with two groups of receptors, the $\mathrm{D}_{1}$-like $\left(\mathrm{D}_{1}, \mathrm{D}_{5}\right)$ and $\mathrm{D}_{2}$-like $\left(\mathrm{D}_{2}, \mathrm{D}_{3}, \mathrm{D}_{4}\right.$, and their variants) DA receptors (Baldessarini and Tarazi 1996; Neve and Neve 1997). Interactions with DA receptors probably mediate beneficial and many adverse effects 
characteristic of antipsychotic drugs (Baldessarini 1996; Neve and Neve 1997). There is a keen interest in developing novel antipsychotics with less adverse effects but similar or even superior beneficial effects on standard agents. A major step in that direction was the prototype agent clozapine, which has an atypically limited risk of adverse extrapyramidal effects or hyperprolactinemia as well as superior antipsychotic effectiveness (Baldessarini and Frankenburg 1991). However, since use of clozapine is limited due to its high risk of potentially fatal bone marrow toxicity and other adverse effects, including excessive sedation and seizures, there is great interest in defining neuropharmacologic characteristics of clozapine that may lead to safer, improved antipsychotics.

Actions of clozapine that may contribute to its unique properties include antagonistic effects at serotonin 5- $\mathrm{HT}_{2}$ and muscarinic acetylcholine receptors, balanced with moderate affinity for both $D_{1}$ and $D_{2}$ receptors (Baldessarini and Frankenburg 1991; Meltzer 1991; Brunello et al. 1995; Baldessarini 1996). Clozapine also shows somewhat greater affinity for $\mathrm{D}_{4}$ than for other DA receptors (Van Tol et al. 1991; Roth et al. 1995; Baldessarini et al. 1997; Kebabian et al. 1997). Moreover, repeated treatment with clozapine results in selective upregulation of putative $\mathrm{D}_{4}$-like, but not $\mathrm{D}_{2}$, receptors in rat forebrain (Florijn et al. 1997; Tarazi et al. 1997). Interest in the $\mathrm{D}_{4}$ receptor as a potential site of action of antipsychotic agents is further encouraged by observations suggesting that these sites may be upregulated in postmortem brain tissue of patients diagnosed with schizophrenia (Seeman et al. 1993; Murray et al. 1995; Sumiyoshi et al. 1995). Interpretation of these findings remains tentative, however, due to uncertainty about the localization of $\mathrm{D}_{4}$ receptors in mammalian brain (Baldessarini and Tarazi 1996). Estimates of altered levels of $\mathrm{D}_{4}$ receptors in studies cited have been limited to indirect methods involving subtraction of the number of binding sites defined with the $\mathrm{D}_{2,3}$ receptor antagonist $\left[{ }^{3} \mathrm{H}\right]$ raclopride from total binding defined with a nonselective inhibitor of $\mathrm{D}_{2}$-like receptors such as $\left[{ }^{3} \mathrm{H}\right]$ nemonapride. Presence of $\mathrm{D}_{4}$ receptors in human caudate-putamen remains particularly uncertain (Reynolds and Mason 1994, 1995; Lahti et al. 1995), and there may be differences in relative abundance of $D_{4}$ protein and its mRNA between brain regions and across species (Van Tol et al. 1991; Schoots et al. 1995; Suzuki et al. 1995). Clarification awaits development of improved $\mathrm{D}_{4}$-selective agents (Kebabian et al. 1997) or immunohistological techniques (Mrzljak et al. 1996).

The DA partial-agonist derivatives, $\mathrm{S}[+]-\mathrm{N}-n$-propylnorapomorphine ([+]-NPA; Campbell et al. 1985, 1986, 1991), its orally active methylenedioxy prodrug, $\mathrm{S}(+)$-10,11-methylenedioxy-N-n-propylnoraporphine (Campbell et al. 1987) and 11-monohydroxy analog, $\mathrm{S}(+)$-11-hydroxy-N-n-propylnoraporphine (Gao et al.
1988; Campbell et al. 1990) have properties suggestive of atypical antipsychotics. These include inhibition of spontaneous or DA-induced locomotor arousal without catalepsy, weak antagonism of stereotyped gnawing behaviors induced by $\mathrm{R}(-)$-aporphines, regional changes in brain concentrations of neurotensin similar to those of clozapine, and lack of hyperprolactinemia, tolerance, or induction of supersensitivity to DA agonists after repeated administration (Campbell et al. 1985, 1986, 1987, 1991, 1993; Nemeroff et al. 1991; Baldessarini et al. 1994). Mechanisms underlying highly regionally selective behavioral actions of $\mathrm{S}(+)$-aporphines (Campbell et al. 1991) are not well defined, but selective interactions with $\mathrm{D}_{4}$ receptors might be involved (Seeman and Van Tol 1993; Lahti et al. 1993, 1996; Kebabian et al. 1997).

The present study was undertaken to verify $\mathrm{D}_{4}$ selectivity of [+]-NPA, and to test the hypothesis that it induces regionally selective changes in levels of different $\mathrm{D}_{2}$-like DA receptors resembling those of clozapine but not typical antipsychotics, and specifically to test for its long-term upregulation of $\mathrm{D}_{4}$-like sites. Effects of three weeks of daily administration of [+]-NPA on $\mathrm{D}_{2}$-like receptor levels were compared to a typical neuroleptic, fluphenazine, and the atypical antipsychotic, clozapine, using quantitative in vitro receptor autoradiography.

\section{METHODS}

\section{Materials and Animal Subjects}

Radioligands were from New England Nuclear (Boston, $\mathrm{MA}): \mathrm{R}, \mathrm{S}( \pm)-\left[\mathrm{N}-\right.$ methyl $\left.-{ }^{3} \mathrm{H}\right]$ nemonapride (YM-09151-2: $86 \mathrm{Ci} / \mathrm{mmol})$ and $\left[\right.$ methoxy- $\left.{ }^{3} \mathrm{H}\right] \mathrm{S}(-)$-raclopride $(74 \mathrm{Ci} /$ $\mathrm{mmol}$ ); or Amersham (Arlington Heights, IL): $\left[2,3-{ }^{3} \mathrm{H}\right]$ $\mathrm{R}(+)$-7-hydroxy-N,N-di-n-propyl-2-amino-1,2,3,4-tetrahydronaphthalene (7-OH-DPAT: $116 \mathrm{Ci} / \mathrm{mmol}$ ) and $\left[2,3,4-{ }^{3} \mathrm{H}\right]$ spiperone $(114 \mathrm{Ci} / \mathrm{mmol})$.

DTG (1,3-ditolylguanidine), S(-)-eticlopride- $\mathrm{HCl}$, cisflupenthixol-di-HCl, fluphenazine-di- $\mathrm{HCl}$, ketanserin tartrate, L-745,870, pindolol, and S(-)-sulpiride were from Research Biochemicals International (RBI, Natick, MA). $\mathrm{S}[+]-\mathrm{N}-n$-propylnorapomorphine- $\mathrm{HCl}([+]-\mathrm{NPA})$, as well as frozen transfected cell membranes expressing human $\mathrm{D}_{2}$ (human $\mathrm{D}_{2 \mathrm{~L}}$ in Sf-9 cells) and $\mathrm{D}_{4}$ receptors (human $\mathrm{D}_{4.2}$ receptors in $\mathrm{CHO}$ cells) also were provided by an NIMH-RBI program. Drug gifts included clozapine from Sandoz Research (Berne, Switzerland) and haloperidol from McNeil Labs. (Ft. Washington, PA). Cation hydrochlorides, guanosine-5'-triphosphate sodium (GTP), leupeptin, phenylmethylsulfonyl fluoride (PMSF), polyethyleneimine (PEI), and tris-(hydroxymethyl)-aminomethane-HCL (Tris), were purchased from Sigma Chemicals (St. Louis, MO).

Animals were male Sprague-Dawley rats (Charles River Labs, Wilmington, MA) initially weighing 200$225 \mathrm{~g}$, maintained under controlled light, temperature, 
and humidity with free access to standard rat chow and tapwater in a USDA-inspected, veterinarian-supervised, small-animal research facility of the Mailman Research Center, with approval by the McLean Hospital Institutional Animal Care and Use Committee (Campbell et al. 1993).

\section{In Vitro Receptor Affinities}

Frozen membranes of genetically transfected cells were thawed and diluted as recommended by the supplier to provide $6\left(\mathrm{D}_{2}\right)$ or $50 \mu \mathrm{g}\left(\mathrm{D}_{4}\right)$ membrane protein/assay in Tris- $\mathrm{HCl}(50 \mathrm{mM}, \mathrm{pH} 7.4)$ containing for $\mathrm{D}_{2}$ assays: 150 $\mathrm{mM} \mathrm{NaCl}\left(\mathrm{D}_{2}\right)$; or $\mathrm{D}_{4}$ assays: $(\mathrm{mM}): \mathrm{NaCl}(120), \mathrm{KCl}$ (5.0), $\mathrm{CaCl}_{2}$ (1.5), EDTA (5.0), and protease inhibitors PMSF (1.0) and leupeptin (0.002). $\left[{ }^{3} \mathrm{H}\right]$ spiperone (free concentration $=\mathrm{F}=0.1 \mathrm{nM},\left[\mathrm{D}_{2}\right]$ or $\left.0.5 \mathrm{nM}\left[\mathrm{D}_{4}\right]\right)$ was incubated with haloperidol $\left(1 \mu \mathrm{M},\left[\mathrm{D}_{2}\right]\right.$ or $\left.10 \mu \mathrm{M}\left[\mathrm{D}_{4}\right]\right)$ to define nonspecific binding; its difference from total binding was considered specific binding (B). In other preliminary experiments, homogenates of rat corpus striatum were incubated with $\left[{ }^{3} \mathrm{H}\right]$ spiperone or $\left[{ }^{3} \mathrm{H}\right]$ nemonapride $\left(\mathrm{D}_{2}\right.$ buffer, $60 \mathrm{~min}, 25^{\circ} \mathrm{C}$; blank $=10 \mu \mathrm{M}$ haloperidol), with a wide range of 12 concentrations (0.1 $\mathrm{nM}-10 \mu \mathrm{M}$ ) of $\mathrm{S}(-)$-raclopride (Baldessarini et al. 1992). $\mathrm{D}_{2}$ assays with cell membranes were conducted for 60 minutes at $27^{\circ} \mathrm{C}$, and $\mathrm{D}_{4}$ assays for 150 minutes at $25^{\circ} \mathrm{C}$. Agents were tested at six or more concentrations in duplicate. Incubations were terminated by immersion in an ice bath, followed by rapid filtration in a cell harvester (Brandel, Gaithersburg, MD) on SS34 (for $\mathrm{D}_{2}$ ) or SS32 $\left(D_{4}\right)$ glass fiber filter sheets (Schleicher-Schuell, Keene, NH) impregnated with $0.3 \%$ (w/v) PEI; samples were counted in $3.5 \mathrm{ml}$ Polyfluor (Packard, Downers Grove, IL) in a scintillation spectrophotometer (Wallace, Gaithersburg, MD) at ca. $50 \%$ efficiency. $\mathrm{IC}_{50} \pm \mathrm{SE}$ was obtained with the ALLFIT program to fit percent inhibition of specific binding vs. test agent concentration, and converted to Ki from the Cheng-Prusoff relationship, $\mathrm{Ki}=\mathrm{IC}_{50} /(1+\mathrm{F} / \mathrm{Kd})$, where $\mathrm{F}$ is free radioligand concentration and $\mathrm{Kd}$ is the independently determined radioligand affinity $\left(\mathrm{Kd}=0.22 \mathrm{nM}\right.$ in the $\mathrm{D}_{2}$, and $0.21 \mathrm{nM}$ in the $\mathrm{D}_{4}$ assay), all as described previously (Kula et al. 1994).

\section{Drug Treatment and Tissue Preparation}

Four groups of rats ( $\mathrm{N}=7$ /group) received intraperitoneal (i.p.) injections at $1 \mathrm{ml} / \mathrm{kg}$ body wt daily for 21 days with doses defined as $\mathrm{mg}$ of salts. Two groups were injected once daily $(08: 00 \mathrm{~h})$ with physiological saline $(0.9 \% \mathrm{w} / \mathrm{v})$ or fluphenazine- $(\mathrm{HCl})_{2}(1 \mathrm{mg} / \mathrm{kg}) ; \mathrm{a}$ third received clozapine base $(20 \mathrm{mg} / \mathrm{kg}$, twice daily: 08:00 and 20:00 h); and a fourth received (+)-NPA-HCl ( $2 \mathrm{mg} / \mathrm{kg}$, thrice daily: 08:00, 14:00, and 20:00 h). At $24 \mathrm{~h}$ after final injections, rats were decapitated and their brains quickly removed, frozen in chilled isopentane, and stored at $-80^{\circ} \mathrm{C}$ until use. Coronal sections $(10 \mu \mathrm{m})$ were cut from ca. $0.2-4.2 \mathrm{~mm}$ anterior to the bregma (Paxinos and Watson 1982) in a cryostat at $-20^{\circ} \mathrm{C}$, mounted on gelatin-coated microscopic slides, and stored at $-20^{\circ} \mathrm{C}$ until thawed at room temperature (rt) for autoradiography.

\section{Receptor Labeling for Autoradiography}

To reduce variance, brain samples from subjects exposed to all treatment conditions were evaluated at one time in each radioreceptor assay, following preincubation of brain sections for $1 \mathrm{~h}$ at $\mathrm{rt}$ in $50 \mathrm{mM}$ Tris- $\mathrm{HCl}$ buffer ( $\mathrm{pH}$ 7.4) containing (mM): $\mathrm{NaCl}$ (120), $\mathrm{KCl}(5)$, $\mathrm{CaCl}_{2}(2)$, and $\mathrm{MgCl}_{2}(1)$, for the $\mathrm{D}_{2}$-like and $\mathrm{D}_{4}$-like assays, or a modification for the $\mathrm{D}_{3}$ assay ( $0.3 \mathrm{mM}$ GTP, 40 $\mathrm{mM} \mathrm{NaCl}$, no $\mathrm{MgCl}_{2}$ ).

For assays of $D_{2}$-like receptors, sections were incubated in the same buffer with one of three combinations of radioligand and masking agents: [1] $1.0 \mathrm{nM}\left[{ }^{3} \mathrm{H}\right]$ nemonapride $\left(\mathrm{D}_{2,3,4}\right)$ with $0.5 \mu \mathrm{M}$ 1,3-ditolylguanidine (DTG) and $0.1 \mu \mathrm{M}$ pindolol to mask sigma $\left(\sigma_{1,2}\right)$ and $5 \mathrm{HT}_{1 \mathrm{~A}}$ sites, respectively (Lahti et al. 1995); [2] $\left.1.2 \mathrm{nM} \mathrm{[}{ }^{3} \mathrm{H}\right]$ spiperone $\left(\mathrm{D}_{2,3,4}\right)$ with $40 \mathrm{nM}$ ketanserin (to block $5-\mathrm{HT}_{2}$-like sites); or [3] $5 \mathrm{nM}\left[{ }^{3} \mathrm{H}\right]$ raclopride $\left(\mathrm{D}_{2,3}\right)$ alone (Tarazi et al. 1997). Incubation continued for $1 \mathrm{~h}$ at rt. Nonspecific binding was determined with $10 \mu \mathrm{M} \mathrm{S}(-)$-sulpiride with $\left[{ }^{3} \mathrm{H}\right]$ nemonapride or $1 \mu \mathrm{M}$ cis-flupenthixol with $\left[{ }^{3} \mathrm{H}\right]$ spiperone and $\left[{ }^{3} \mathrm{H}\right]$ raclopride.

For $D_{3}$ receptor binding, sections were preincubated for $1 \mathrm{~h}$ in a modified Tris buffer, already described. Sections were then incubated in the same buffer for $1 \mathrm{~h}$, with $3 \mathrm{nM}\left[{ }^{3} \mathrm{H}\right] 7-\mathrm{OH}-\mathrm{DPAT}$ and $5 \mu \mathrm{M}$ DTG added to mask sigma sites (Wallace and Booze 1995). Nonspecific binding was determined with $1 \mu \mathrm{M} \mathrm{S}(-)$-eticlopride. After incubation, slides were washed twice for $3 \mathrm{~min}$ utes in ice-cold, fresh buffer and dried under a stream of air. With the partially $\mathrm{D}_{3}$-selective agonist radioligand, $\left[{ }^{3} \mathrm{H}\right] \mathrm{R}(+)-7-\mathrm{OH}-\mathrm{DPAT}, \mathrm{Na}^{+}(40 \mathrm{mM})$ and GTP $(0.3$ $\mathrm{mM}$ ) were included and $\mathrm{Mg}^{2+}$ excluded, to avoid labeling the high-affinity agonist binding state of $\mathrm{D}_{2}$ receptors by driving $\mathrm{D}_{2}$ receptors into their agonist low-affinity state (Gonzalez and Sibley 1995).

For $D_{4}$-like assays, an optimal concentration of $\mathrm{S}(-)$ raclopride to fully block $D_{2}$ and $D_{3}$ receptors selectively was determined with a range of concentrations of unlabeled raclopride to compete vs. $\left[{ }^{3} \mathrm{H}\right]$ nemonapride in rat forebrain sections (Florijn et al. 1997; Tarazi et al. 1997). Curve-fitting optimized with a two site model indicated that $300 \mathrm{mM}$ raclopride fully occupied a high-affinity binding component (presumably $\mathrm{D}_{2}$ and $\mathrm{D}_{3}$ receptors), but not residual specific binding (ca. 20\%) that may represent $D_{4}$-like sites (Seeman et al. 1995). Similar evidence of two components of binding defined with a range of concentrations of $\mathrm{S}(-)$-raclopride vs. $\left[{ }^{3} \mathrm{H}\right]-$ nemonapride and $\left[{ }^{3} \mathrm{H}\right]$ spiperone was found preliminar- 
ily with rat striatal homogenates; the first component represented ca. $80 \%$ of all specific binding with both radioligands. The $\mathrm{D}_{4}$ assays employed: [1] $1.0 \mathrm{nM}\left[{ }^{3} \mathrm{H}\right]$ nemonapride with $0.5 \mu \mathrm{M}$ DTG, $0.1 \mu \mathrm{M}$ pindolol, and excess $\mathrm{S}(-)$-raclopride $(0.3 \mu \mathrm{M})$, or [2] $1.2 \mathrm{nM}\left[{ }^{3} \mathrm{H}\right]$ spiperone with $40 \mathrm{nM}$ ketanserin and same concentration of $\mathrm{S}(-)$-raclopride to mask $\mathrm{D}_{2}, \mathrm{D}_{3}$, and other nonspecific binding sites, and reveal $\mathrm{D}_{4}$-like receptors (Florijn et al. 1997; Tarazi et al. 1997). Non-specific binding determined with $10 \mu \mathrm{M} \mathrm{S}(-)$-sulpiride with $\left[{ }^{3} \mathrm{H}\right]$ nemonapride and $1 \mu \mathrm{M}$ cis-flupenthixol with $\left[{ }^{3} \mathrm{H}\right]$ spiperone. After each radioligand assay, slides were washed twice for 5 min in ice-cold buffer, dipped in ice-cold deionized water, and then dried in a stream of air. The $\mathrm{D}_{4}$-selective ligand L-745,870 (Kulagowski et al. 1996; Kebabian et al. 1997) was used to characterize the raclopride-insensitive component of binding with both radioligands.

\section{Autoradiography and Image Analysis}

Radiolabeled slides and calibrated $\left[{ }^{3} \mathrm{H}\right]$ standards (Amersham) were exposed to Hyperfilm (Eastman-Kodak, Rochester, NY) for $2-5$ weeks at $4^{\circ} \mathrm{C}$. $\left[{ }^{3} \mathrm{H}\right]$ Nemonapridelabeled brain sections were exposed for 2 weeks (caudate-putamen $[\mathrm{CPu}]$ and nucleus accumbens[ACC]) for 5 weeks (cerebral cortex) to compensate for lower receptor abundance; $\left[{ }^{3} \mathrm{H}\right]$ spiperone was exposed for 2 weeks; $\left[{ }^{3} \mathrm{H}\right]$ raclopride and $\left[{ }^{3} \mathrm{H}\right] 7-\mathrm{OH}-\mathrm{DPAT}$, for 4 weeks. These exposures provided optical densities within the linear range of the tritium-sensitive film, which was developed in Kodak D-19 developer and fixative. Optical density (OD) in brain regions of interest was measured with a computerized densitometric image analyzer
(MCID-M4, Imaging Research, St. Catharines, Ontario). Brain regions of interest were outlined (Figure 1) and their OD was measured. Left and right sides of two contiguous sections (4 measurements/subject-brain) represented total binding and two other sections represented nonspecific binding; the four determinations were averaged for each subject ( $\mathrm{N}=7$ subjects for each treatment condition). OD was converted to $\mathrm{nCi} / \mathrm{mg}$ of tissue with calibrated $\left[{ }^{3} \mathrm{H}\right]$ standards and, after subtracting non-specific from total binding to compute specific binding, expressed as fmol/mg tissue.

\section{Statistical Analysis}

Two-way analysis of variance (ANOVA) with each autoradiographic assay initially tested for effects of drug treatments in preselected brain regions; given overall significance, post-hoc Dunnett $t$-tests identified significant differences between treatment groups. Unless stated otherwise, data are presented as means \pm SEM. Comparisons were considered significant at $p<0.05$ in two-tailed tests, with degrees of freedom (df) based on $\mathrm{N}$ subjects/treatment group.

\section{RESULTS}

Preliminary experiments with transfected cell membranes (Table 1) confirmed that the new $\mathrm{D}_{4}$ ligand L-745,870 (Kulagowski et al. 1996; Kebabian et al. 1997) showed expected high $\mathrm{D}_{4}$ affinity and selectivity, whereas clozapine and (+)-NPA had similar and more moderate $\mathrm{D}_{4}$ affinity, though (+)-NPA had somewhat higher $\mathrm{D}_{4}{ }^{-}$
A
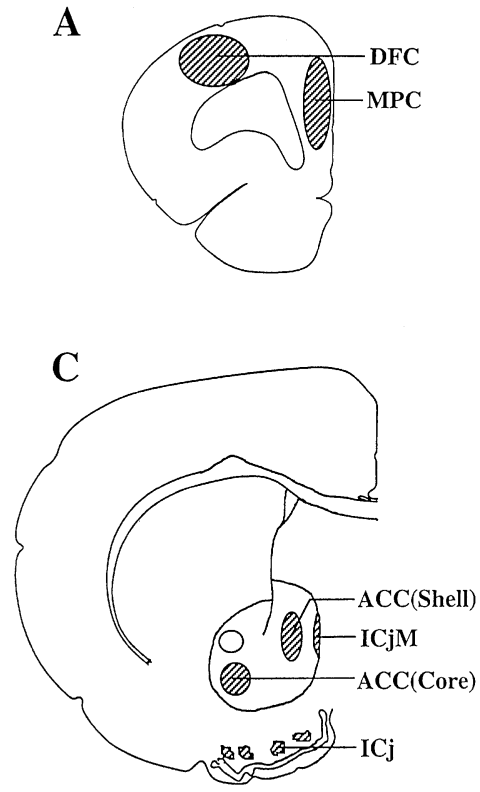

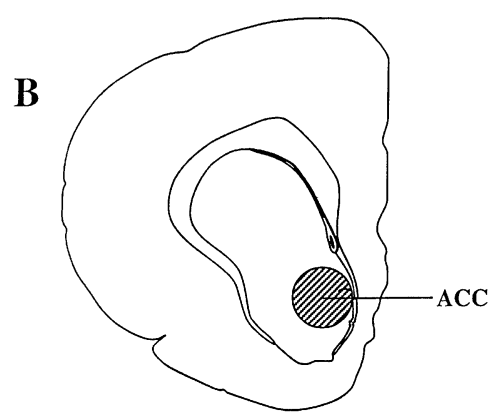

D

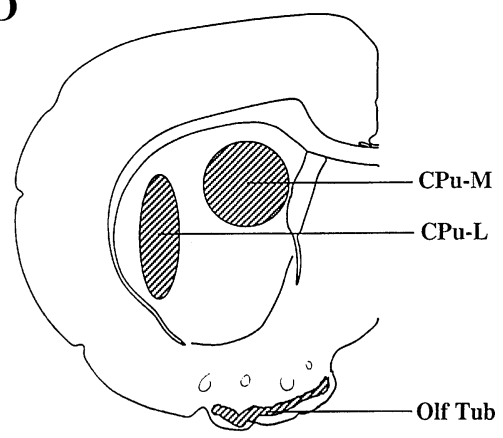

Figure 1. Sites for autoradiographic analyses of rat brain regions. Samples included 10 $\mu \mathrm{m}$ coronal sections from: A (A 3.2-4.2), B (A 1.7-2.2), C (A 0.7-1.2), and D (A 0.2-0.7 mm anterior to bregma according to Paxinos and Watson, 1982). ACC, nucleus accumbens septi (core and shell subdivisions); $C P u$, caudate-putamen ( $L$, lateral and $M$, medial); $D F C$, dorsolateral frontal cerebral cortex; $I C j$, islands of Calleja; ICjM, major island of Calleja; MPC, "medial prefrontal" (cingulate or anterior limbic) cerebral cortex; Olf Tub, olfactory tubercle. 
Table 1. Affinities to Dopamine Receptors in Membranes of Transfected Cells

\begin{tabular}{lccc}
\hline & \multicolumn{2}{c}{ Ki (nM 6 SE) } & Affinity \\
\cline { 2 - 3 } Agent & $\mathbf{D}_{2 \mathrm{~L}}$ & $\mathbf{D}_{4.2}$ & Ratio \\
\hline Nemonapride & $0.015 \pm 0.012$ & $0.280 \pm 0.020$ & 0.05 \\
Spiperon & $0.250 \pm 0.001$ & $0.073 \pm 0.006$ & 3.4 \\
Clozapine & $262 \pm 25$ & $43.6 \pm 8.5$ & 6.0 \\
S(+)-NPA & $774 \pm 118$ & $56.4 \pm 9.5$ & 13.7 \\
L-745,870 & $>10,000$ & $0.59 \pm 0.07$ & $>10,000$ \\
\hline
\end{tabular}

Assays and analyses are described in Methods, using $\left[{ }^{3} \mathrm{H}\right]$ spiperone as radioligand. The affinity ratio $\left(\mathrm{Ki}_{2} / \mathrm{Ki}_{4}\right)$ inidicates $\mathrm{D}_{4}$ preference.

over- $\mathrm{D}_{2}$ selectivity than clozapine. In addition, $1 \mu \mathrm{M} \mathrm{L-}$ 745,870 reduced the raclopride-insensitive component of $\left[{ }^{3} \mathrm{H}\right]$ spiperone and $\left[{ }^{3} \mathrm{H}\right]$ nemonapride binding to $\mathrm{D}_{4^{-}}$ like sites in sections of rat forebrain from $40.7 \pm 2.1$ and $15.9 \pm 0.8$ to $10.5 \pm 0.8$ and $3.2 \pm 0.2 \mathrm{fmol} / \mathrm{mg}$ tissue respectively, reflecting a displacement of $74-80 \%$ of $\mathrm{D}_{4}$ like binding sites in the $\mathrm{CPu}$, but had no significant effect on $\left[{ }^{3} \mathrm{H}\right]$ nemonapride binding to mainly $\mathrm{D}_{2}$-like receptors $(106.8 \pm 2.9$ vs. $117.4 \pm 3.2 \mathrm{fmol} / \mathrm{mg}$, with or without L-745,870 added). These observations indicate that the great majority of the raclopride-insensitive $\mathrm{D}_{4^{-}}$ like binding sites reported here are probably $\mathrm{D}_{4}$ receptors.

Three weeks of single daily injections of fluphenazine significantly increased binding of the non-selective $\mathrm{D}_{2,3,4}$ radioligands $\left[{ }^{3} \mathrm{H}\right]$ nemonapride and $\left[{ }^{3} \mathrm{H}\right]$ spiperone in the limbic ACC (67\% and $52 \%$, respectively), olfactory tubercle (OT: $53 \%$ and $43 \%$ ), and $\mathrm{CPu}$ (average $22 \%, 32 \%$ ) (Tables 2 and 3). In contrast, fluphenazine induced less increase in binding of the $\mathrm{D}_{2,3}$ radioligand $\left[{ }^{3} \mathrm{H}\right]$ raclopride in both ACC $(27 \%)$ and $\mathrm{CPu}$ (average, $16 \%$ ) (Table 4). Repeated daily treatment with (+)-NPA and clozapine did not significantly change binding of any of the three radioligands in ACC or CPu (Tables 24). However, significant increases in $\left[{ }^{3} \mathrm{H}\right]$ nemonapride and $\left[{ }^{3} \mathrm{H}\right]$ spiperone binding were observed in "medial prefrontal" cerebral cortex (MPC, containing cingulate or anterior limbic cortex), but not dorsolateral frontal cortex (DFC), following treatment with fluphenazine (46\% and $47 \%$, respectively), (+)-NPA $(48 \%, 39 \%)$, or clozapine (59\%, 40\%) (Tables 2 and 3). Repeated treatment with all three drugs also did not significantly affect binding of $\left[{ }^{3} \mathrm{H}\right] 7-\mathrm{OH}-\mathrm{DPAT}$ to $\mathrm{D}_{3}$ receptors in the islands of Calleja, where it was most abundant, nor in ACC shell or core subregions, OT, or $\mathrm{CPu}$ (Table 5).

$\mathrm{D}_{4}$-like sites were labeled with $\left[{ }^{3} \mathrm{H}\right]$ nemonapride or $\left[{ }^{3} \mathrm{H}\right]$ spiperone in the presence of masking agents to occlude additional binding sites. Labeling with $\left[{ }^{3} \mathrm{H}\right]$ nemonapride plus unlabeled raclopride (Table 6) indicated that repeated treatment with fluphenazine, (+)-NPA, and clozapine all induced large increases in $\mathrm{D}_{4}$-like binding in ACC $(124 \%, 69 \%$, and $71 \%$, respectively) and $\mathrm{CPu}$ (average, $62 \%, 47 \%$, and $43 \%$ ). Similarly, $\left[{ }^{3} \mathrm{H}\right]$ spiperone binding (Table 7) was increased significantly by fluphenazine, $(+)-\mathrm{NPA}$, and clozapine in ACC $(115 \%$, $71 \%$, and $80 \%$ ) and $\mathrm{CPu}$ (average, $46 \%, 24 \%$, and $32 \%$ ). Percent changes in $\mathrm{D}_{4}$-like binding in the 18 comparisons with $\left[{ }^{3} \mathrm{H}\right]$ nemonapride vs. $\left[{ }^{3} \mathrm{H}\right]$ spiperone (Tables 6 and 7) were highly correlated $(r=0.93$; slope $=0.95$, $\mathrm{p}<0.0001)$.

To summarize, when $\left[{ }^{3} \mathrm{H}\right]$ nemonapride and $\left[{ }^{3} \mathrm{H}\right]$ spiperone labeled mainly the highly prevalent $\mathrm{D}_{2}$ receptors, fluphenazine as well as (+)-NPA and clozapine all produced substantial increases of $\mathrm{D}_{2}$-like receptor binding in the rat $\mathrm{MP} \times \mathrm{C}$, but only the typical antipsychotic fluphenazine produced significant increases of these receptors in ACC or CPu (Tables 2 and 3, Figure 2A). In contrast, in the presence of raclopride to occlude $\mathrm{D}_{2}$ and $\mathrm{D}_{3}$ sites and reveal $\mathrm{D}_{4}$-like sites selectively, all three agents had only minor effects in MPC, but produced large increases of $\mathrm{D}_{4}$-like abundance in $\mathrm{CPu}$ and especially in ACC (Tables 6 and 7, Figure 2B).

\section{DISCUSSION}

The present autoradiographic findings indicate that in the rat's ACC and CPu tissues, fluphenazine pretreat-

Table 2. $\quad\left[{ }^{3} \mathrm{H}\right]$ Nemonapride Binding to $\mathrm{D}_{2}$-Like $\left(\mathrm{D}_{2,3,4}\right)$ Receptors after Three Weeks of Daily Antipsychotic Treatment

\begin{tabular}{lcccc}
\hline Brain Region & Controls & Fluphenazine & (+)-NPA & Clozapine \\
\hline Cerebral cortex & & & & \\
$\quad$ Medial-prefrontal & $14.2 \pm 0.9(100)$ & $20.8 \pm 0.4(\mathbf{1 4 6})^{*}$ & $21.1 \pm 1.5(\mathbf{1 4 9})^{*}$ & $22.7 \pm 1.7(\mathbf{1 6 0})^{*}$ \\
$\quad$ Dorsolateral & $12.2 \pm 1.0(100)$ & $11.2 \pm 1.0(92)$ & $12.2 \pm 1.0(100)$ & $13.5 \pm 0.6(111)$ \\
Nucleus accumbens & $83.0 \pm 2.6(100)$ & $138.4 \pm 4.3(\mathbf{1 6 7})^{*}$ & $91.7 \pm 4.6(110)$ & $85.3 \pm 4.4(103)$ \\
Caudate-putamen & & & & $138.6 \pm 3.9(103)$ \\
$\quad$ Lateral & $134.9 \pm 3.1(100)$ & $158.3 \pm 4.6(\mathbf{1 1 7})^{*}$ & $101.8 \pm 5.0(102)$ & $104.2 \pm 4.3(104)$ \\
$\quad$ Medial & $99.8 \pm 3.2(100)$ & $125.8 \pm 4.4(\mathbf{1 2 6})^{*}$ & $53.3 \pm 4.2(99)$ & $56.9 \pm 4.1(106)$ \\
Olfactory tubercle & $53.6 \pm 2.1(100)$ & $82.1 \pm 5.2(\mathbf{1 5 3})^{*}$ & &
\end{tabular}

Data are mean \pm SEM values for binding ( $\mathrm{fmol} / \mathrm{mg}$ tissue and $\%$ of control), determined by quantitative autoradiography following antipsychotic or control injections daily for 3 weeks, with significant differences from controls indicated ([*], bold: $(\mathrm{p}<0.05, \mathrm{~N}=7$ rats/group), all as described in Methods. 
Table 3. $\left[{ }^{3} \mathrm{H}\right]$ Spiperone Binding to $\mathrm{D}_{2}$-Like $\left(\mathrm{D}_{2,3,4}\right)$ Receptors after Three Weeks of Daily Antipsychotic Treatment

\begin{tabular}{lcccc}
\hline Brain Region & Controls & Fluphenazine & (+)-NPA & Clozapine \\
\hline Cerebral cortex & & & & \\
$\quad$ Medial-prefrontal & $33.2 \pm 2.0(100)$ & $48.9 \pm 1.7(\mathbf{1 4 7})^{*}$ & $46.2 \pm 2.1(\mathbf{1 3 9})^{*}$ & $46.4 \pm 1.0(\mathbf{1 4 0})^{*}$ \\
$\quad$ Dorsolateral & $26.9 \pm 2.4(100)$ & $26.2 \pm 3.5(97)$ & $25.4 \pm 3.0(94)$ & $27.6 \pm 1.3(102)$ \\
$\quad$ Nucleus accumbens & $80.5 \pm 4.2(100)$ & $122.2 \pm 4.1(\mathbf{1 5 2})^{*}$ & $84.6 \pm 3.6(105)$ & $82.9 \pm 4.0(115)$ \\
$\quad$ Caudate-putamen & & & \\
$\quad$ Lateral & $123.5 \pm 4.2(100)$ & $159.5 \pm 3.4(\mathbf{1 2 9})^{*}$ & $130.6 \pm 3.9(106)$ & $135.9 \pm 2.5(110)$ \\
$\quad$ Medial & $89.3 \pm 2.8(100)$ & $120.1 \pm 3.3(\mathbf{1 3 4})^{*}$ & $98.3 \pm 4.4(110)$ & $101.4 \pm 2.3(114)$ \\
Olfactory tubercle & $83.7 \pm 2.5(100)$ & $119.9 \pm 4.3(\mathbf{1 4 3})^{*}$ & $77.5 \pm 4.0(93)$ & $74.0 \pm 5.3(88)$ \\
\hline
\end{tabular}

Data are mean \pm SEM values for binding ( $\mathrm{fmol} / \mathrm{mg}$ tissue and $\%$ of control), determined by quantitative autoradiography following antipsychotic or control injections daily for 3 weeks, with significant differences from controls indicated ([*], bold: $\mathrm{p}<0.05, \mathrm{~N}=7$ rats / group), all as described in Methods.

ment induced large increases in $\mathrm{D}_{2}$-like receptor binding of $\left[{ }^{3} \mathrm{H}\right]$ nemonapride and $\left[{ }^{3} \mathrm{H}\right]$ spiperone (ligands for $\mathrm{D}_{2,3,4}$ receptors), with smaller increases in $\left[{ }^{3} \mathrm{H}\right]$ raclopride binding (selective for $\mathrm{D}_{2,3}$ receptors) and no changes in the binding of $\left[{ }^{3} \mathrm{H}\right] \mathrm{R}[+]-7-\mathrm{OH}-\mathrm{DPAT}$ under $\mathrm{D}_{3}$-selective assay conditions (Tables 2-5). Similarly, greater increases in the binding of $\left[{ }^{3} \mathrm{H}\right]$ nemonapride and $\left[{ }^{3} \mathrm{H}\right]$ spiperone, than $\left[{ }^{3} \mathrm{H}\right]$ raclopride, have been reported in $\mathrm{CPu}$ tissue in mainly neuroleptic-treated patients diagnosed with schizophrenia, in both postmortem radioreceptor assays and clinical brain scanning (Wong et al. 1986; Farde et al. 1990; Seeman et al. 1993; Murray et al. 1995; Sumiyoshi et al. 1995; Neve and Neve 1997). Nemonapride and spiperone have relatively high affinity for cloned $\mathrm{D}_{2}, \mathrm{D}_{3}$, and $\mathrm{D}_{4}$ receptors expressed in genetically transfected cells $(\mathrm{Ki}=0.07$ $0.61 \mathrm{nM}$ ) (Sokoloff et al. 1990; Van Tol et al. 1991), whereas raclopride has high affinity (1.8 and $3.5 \mathrm{nM})$ for cloned $D_{2}$ and $D_{3}$ receptors, but much lower affinity for cloned $\mathrm{D}_{4}$ receptors $(2.0 \mu \mathrm{M})$ (Seeman et al. 1993). The difference in radioligand binding defined by nemonapride or spiperone compared to raclopride may correspond to $\mathrm{D}_{4}$-like receptors or binding sites (Seeman et al. 1993, 1995).

The differential affinity of DA antagonists to specific types of $\mathrm{D}_{2}$-like receptors led to the present assays based on including a saturating concentration of raclopride to occlude $D_{2}$ and $D_{3}$ receptors selectively, so that the remaining binding of $\left[{ }^{3} \mathrm{H}\right]$ nemonapride or $\left[{ }^{3} \mathrm{H}\right]$ spiperone would predominantly represent $\mathrm{D}_{4}$ or $\mathrm{D}_{4}$-like binding sites (Florijn et al. 1997; Tarazi et al. 1997). This conclusion is supported by finding that the highly $\mathrm{D}_{4}$ selective ligand L-745,870 occluded most $(74-80 \%)$ of the raclopride-insensitive binding of $\left[{ }^{3} \mathrm{H}\right]$ nemonapride or $\left[{ }^{3} \mathrm{H}\right]$ spiperone to rat striatal sections, in the presence of other agents used to mask other relevant non-DA receptor sites. These included pindolol to occlude $5-\mathrm{HT}_{1 \mathrm{~A}}$ serotonin receptors and DTG to mask sigma sites in the presence of $\left[{ }^{3} \mathrm{H}\right]$ nemonapride, and with ketanserin added to block 5- $\mathrm{HT}_{2}$-like receptors in the presence of $\left[{ }^{3} \mathrm{H}\right]$ spiperone.

Consistently higher estimates of $\mathrm{D}_{4}$-like binding $\left(\mathrm{fmol} / \mathrm{mg}\right.$ ) were obtained with $\left[{ }^{3} \mathrm{H}\right]$ spiperone than with $\left[{ }^{3} \mathrm{H}\right]$ nemonapride in all brain regions studied with $\left[{ }^{3} \mathrm{H}\right]$ spiperone vs. $\left[{ }^{3} \mathrm{H}\right]$ nemonapride (in 24 comparisons based on data in Tables 6 and 7: slope $=2.41, r=0.99, p<$ $0.0001)$. These radioligands were assayed at similar concentrations (1.0-1.2 $\mathrm{nM}$ ) but spiperone has 38-fold greater $\mathrm{D}_{4}$ affinity and is much more $\mathrm{D}_{4}$-over- $\mathrm{D}_{2}$ selective than nemonapride. Thus, spiperone showed much higher affinity for $D_{4.2}$ than $D_{2 L}$ receptors (3.42-fold) in transfected cell membranes assayed with $\left[{ }^{3} \mathrm{H}\right]$ spiperone,

Table 4. $\quad\left[{ }^{3} \mathrm{H}\right]$ Raclopride Binding to $\mathrm{D}_{2}$ and $\mathrm{D}_{3}$ Receptors after Three Weeks of Daily Antipsychotic Treatment

\begin{tabular}{lcccc}
\hline Brain Region & Controls & Fluphenazine & (+)-NPA & Clozapine \\
\hline Nucleus accumbens & $35.5 \pm 2.0(100)$ & $45.2 \pm 1.8(\mathbf{1 2 7})^{*}$ & $37.3 \pm 1.4(105)$ & $39.0 \pm 2.7(110)$ \\
Caudate-putamen & & & & \\
$\quad$ Lateral & $57.3 \pm 1.1(100)$ & $64.8 \pm 0.6(\mathbf{1 1 3})^{*}$ & $57.6 \pm 2.2(101)$ & $60.1 \pm 2.1(105)$ \\
$\quad$ Medial & $40.6 \pm 1.9(100)$ & $47.8 \pm 0.6(\mathbf{1 1 8})^{*}$ & $40.3 \pm 1.4(99)$ & $41.9 \pm 1.4(103)$ \\
\hline
\end{tabular}

Data are mean \pm SEM values for binding (fmol/mg tissue and $\%$ of control), determined by quantitative autoradiography following antipsychotic or control injections daily for 3 weeks, with significant differences from controls indicated ([*], bold: $\mathrm{p}<0.05, \mathrm{~N}=7$ rats/group), all as described in Methods. 
Table 5. $\quad\left[{ }^{3} \mathrm{H}\right] 7-\mathrm{OH}-\mathrm{DPAT}$ Binding to $\mathrm{D}_{3}$-Like Receptors after Three Weeks of Daily Antipsychotic Treatment

\begin{tabular}{lcccc}
\hline Brain Region & Controls & Fluphenazine & $(+)$-NPA & Clozapine \\
\hline Islands of Calleja & $17.6 \pm 1.3(100)$ & $17.4 \pm 1.4(100)$ & $18.2 \pm 1.6(105)$ & $16.7 \pm 0.9(97)$ \\
Olfactory tubercle & $4.7 \pm 0.3(100)$ & $4.8 \pm 0.5(102)$ & $5.2 \pm 0.3(110)$ & $4.8 \pm 0.2(102)$ \\
Nucleus accumbens & & & & \\
$\quad$ Shell & $7.3 \pm 1.2(100)$ & $7.9 \pm 1.4(108)$ & $8.0 \pm 1.4(109)$ & $6.8 \pm 0.6(93)$ \\
$\quad$ Core & $3.7 \pm 0.5(100)$ & $3.5 \pm 0.5(95)$ & $3.7 \pm 0.4(100)$ & $3.6 \pm 0.3(97)$ \\
Caudate-putamen & $1.6 \pm 0.3(100)$ & $1.9 \pm 0.4(118)$ & $1.4 \pm 0.1(88)$ & $1.6 \pm 0.2(100)$ \\
\hline
\end{tabular}

Data are mean \pm SEM values for binding ( $\mathrm{fmol} / \mathrm{mg}$ tissue and $\%$ of control), determined by quantitative autoradiography following antipsychotic or control injections daily for 3 weeks, $(\mathrm{N}=7$ rats/group), all as described in Methods.

whereas nemonapride was less selective for $\mathrm{D}_{4.2}$ than $\mathrm{D}_{2 \mathrm{~L}}$ sites (by 18.5-fold; Table 1 ). In addition, $\left[{ }^{3} \mathrm{H}\right]$ spiperone may have labeled some nonspecific sites not as effectively excluded with masking agents as with $\left[{ }^{3} \mathrm{H}\right]$ nemonapride. While the present indirect assays may not provide quantitative measures of $\mathrm{D}_{4}$ levels in brain tissue, both radioligands yielded similar displacement of $\mathrm{D}_{4}$-like binding with L-745,870 and similar percentage changes with the drugs tested, supporting at least the qualitative reliability of the findings reported (Tables 6 and 7).

With both radioligands, $\mathrm{D}_{4}$-like binding density $(\mathrm{fmol} / \mathrm{mg})$ in untreated brain tissue was less in cerebral cortex than in ACC and $\mathrm{CPu}$ (Tables 6 and 7) but represented a somewhat higher proportion of all $\mathrm{D}_{2}$-like receptor binding in the cortex than in ACC or $\mathrm{CPu}$ (Tables $2,3,6$, and 7). Higher levels of $\mathrm{D}_{4}$-like binding in ACC and $\mathrm{CPu}$ than in frontal cortex contrast with more abundant expression of $\mathrm{D}_{4}$ mRNA in cerebral cortex than in subcortical regions of rat and human forebrain (Van Tol et al. 1991; Meador-Woodruff 1994, 1996). Some $\mathrm{D}_{4}$-like sites in ACC and CPu may arise on afferent axons with cell bodies in cerebral cortex as well as on intrinsic local neurons (Tarazi et al. 1997) and expression of $\mathrm{D}_{4}$ receptor immunoreactivity has been found in glutamatergic pyramidal cells as well as intrinsic GABAergic neurons in primate cortex (Mrzljak et al. 1996). Failure of typical and atypical antipsychotics to significantly upregulate cortical $\mathrm{D}_{4}$-like sites (Tables 6 and 7) may suggest regional differences in the regulation of $\mathrm{D}_{4}$ genes or protein synthesis and turnover. This suggestion is consistent with a reported lack of increase of both $\mathrm{D}_{4}$ mRNA and receptor protein in rat cortex after treatment with haloperidol, in contrast to a coordinated rise of both message and product in rat striatum (Schoots et al. 1995).

Increased binding of $\left[{ }^{3} \mathrm{H}\right]$ nemonapride and $\left[{ }^{3} \mathrm{H}\right]$ spiperone to $\mathrm{D}_{2}$-like receptors in MPC, and not $\mathrm{DFC}$, by both typical and atypical antipsychotic agents in the present study (Tables 2 and 3) probably reflects a selective increase in $\mathrm{D}_{2}$ receptors, since cortical $\mathrm{D}_{4}$-like binding was not altered by these drugs (Tables 6 and 7) and $\mathrm{D}_{3}$ receptors are infrequent in rat cortex (Sokoloff et al. 1990). Some upregulation of $D_{2}$ receptors in cerebral cortex in response to repeated treatment with both atypical and typical antipsychotic agents has also been

Table 6. Binding of $\left[{ }^{3} \mathrm{H}\right] \mathrm{Nemonapride}$ with Raclopride to $\mathrm{D}_{4}$-Like Receptors after Three Weeks of Daily Antipsychotic Treatment

\begin{tabular}{lllll}
\hline Brain Region & \multicolumn{1}{c}{ Controls } & Fluphenazine & (+)-NPA & Clozapine \\
\hline Cerebral cortex & & & & \\
$\quad$ Medial-prefrontal & $8.62 \pm 0.73(100)$ & $9.18 \pm 1.10(106)$ & $9.90 \pm 0.92(115)$ & $10.1 \pm 0.9(117)$ \\
$\quad$ Dorsolateral & $7.68 \pm 0.54(100)$ & $5.73 \pm 0.73(75)$ & $6.08 \pm 0.69(79)$ & $7.43 \pm 0.72(97)$ \\
Nucleus accumbens & $13.4 \pm 0.9(100)$ & $30.0 \pm 2.2(\mathbf{2 2 4})^{*}$ & $22.6 \pm 2.7(\mathbf{1 6 9})^{*}$ & $22.9 \pm 2.0(\mathbf{1 7 1})^{*}$ \\
Caudate-putamen & & & & \\
$\quad$ Lateral & $18.2 \pm 1.3(100)$ & $29.2 \pm 1.8(\mathbf{1 6 0})^{*}$ & $26.0 \pm 1.6(\mathbf{1 4 3})^{*}$ & $26.0 \pm 2.3(\mathbf{1 4 3})^{*}$ \\
$\quad$ Medial & $13.5 \pm 0.6(100)$ & $22.0 \pm 4.4(\mathbf{1 6 3})^{*}$ & $20.4 \pm 2.3(\mathbf{1 5 1})^{*}$ & $19.3 \pm 0.9(\mathbf{1 4 3})^{*}$ \\
Olfactory tubercle & $6.86 \pm 1.70(100)$ & $7.67 \pm 0.35(112)$ & $8.63 \pm 1.15(126)$ & $6.41 \pm 0.46(93)$ \\
\hline
\end{tabular}

Data are mean \pm SEM values for binding (fmol/mg tissue and \% of control), determined by quantitative autoradiography following antipsychotic or control injections daily for 3 weeks, with significant differences from controls indicated ([*], bold: $\mathrm{p}<0.05, \mathrm{~N}=7$ rats/group), all as described in Methods. 
Table 7. Binding of $\left[{ }^{3} \mathrm{H}\right]$ Spiperone with Raclopride to $\mathrm{D}_{4}$-Like Receptors after Three Weeks of Daily Antipsychotic Treatment

\begin{tabular}{lllll}
\hline Brain Region & \multicolumn{1}{c}{ Controls } & Fluphenazine & (+)-NPA & Clozapine \\
\hline $\begin{array}{l}\text { Cerebral cortex } \\
\quad \text { Medial-prefrontal }\end{array}$ & $17.9 \pm 1.98(100)$ & $17.8 \pm 2.17(99)$ & $18.0 \pm 1.89(101)$ & $16.1 \pm 2.09(90)$ \\
$\quad$ Dorsolateral & $15.9 \pm 2.13(100)$ & $13.5 \pm 1.62(85)$ & $14.4 \pm 2.06(91)$ & $14.0 \pm 1.05(88)$ \\
$\quad$ Nucleus accumbens & $3.12 \pm 24(100)$ & $67.2 \pm 2.8(\mathbf{2 1 5})^{*}$ & $53.3 \pm 2.8(\mathbf{1 7 1})^{*}$ & $56.1 \pm 1.6(\mathbf{1 8 0})^{*}$ \\
Caudate-putamen & & & & \\
$\quad$ Lateral & $44.9 \pm 2.1(100)$ & $67.6 \pm 2.7(\mathbf{1 5 1})^{*}$ & $56.8 \pm 1.2(\mathbf{1 2 7})^{*}$ & $60.5 \pm 1.1(\mathbf{1 3 5})^{*}$ \\
$\quad$ Medial & $35.6 \pm 2.0(100)$ & $50.6 \pm 1.8(\mathbf{1 4 2})^{*}$ & $42.6 \pm 1.4(\mathbf{1 2 0})^{*}$ & $45.5 \pm 1.3(\mathbf{1 2 8})^{*}$ \\
Olfactory tubercle & $14.3 \pm 1.5(100)$ & $12.1 \pm 0.9(85)$ & $15.5 \pm 1.2(108)$ & $15.9 \pm 1.1(111)$ \\
\hline
\end{tabular}

Data are mean \pm SEM values for binding ( $\mathrm{fmol} / \mathrm{mg}$ tissue and $\%$ of control), determined by quantitative autoradiography following antipsychotic or control injections daily for 3 weeks, with significant differences from controls indicated ([*], bold: $\mathrm{p}<0.05, \mathrm{~N}=7$ rats/group), all as described in Methods.

found in rats and primates (Janowsky et al. 1992; Lidow and Goldman-Rakic 1994). Selective increases in MPC, but not $\mathrm{CPu}$ or $\mathrm{ACC}, \mathrm{D}_{2}$ receptors after treatment with the atypical agents clozapine and (+)-NPA (Tables 2 and 3) may reflect differences in the types of $\mathrm{D}_{2}$-like receptors in these brain regions or different regulatory responses of cells which express them.

Neither $D_{2}$ nor $D_{3}$ receptor upregulation was detected in $\mathrm{CPu}$ or ACC after long-term treatment with clozapine or (+)-NPA, and fluphenazine evidently increased $\mathrm{D}_{2}$ but not $\mathrm{D}_{3}$ binding (Florijn et al. 1997; Tarazi et al. 1997) (Tables 4 and 5). Increased $\left[{ }^{3} \mathrm{H}\right]$ raclopride binding in striatum following fluphenazine probably represents $D_{2}$ receptors because $D_{3}$ receptors are found in low levels there, and binding of $\left[{ }^{3} \mathrm{H}\right] \mathrm{R}(+)-7-\mathrm{OH}-$ DPAT under $\mathrm{D}_{3}$-selective conditions (Gonzales and Sibley 1995) was not increased by any of the treatments tested (Table 5), consistent with previous findings after antipsychotic treatment (Levésque et al. 1995; Florijn et al. 1997; Tarazi et al. 1997). Lack of a response of $D_{3}$ receptors to repeated treatment with DA antagonists may reflect their inability to upregulate in response to prolonged blockade, perhaps paralleling their limited or inconsistent interactions with G-proteins and second-
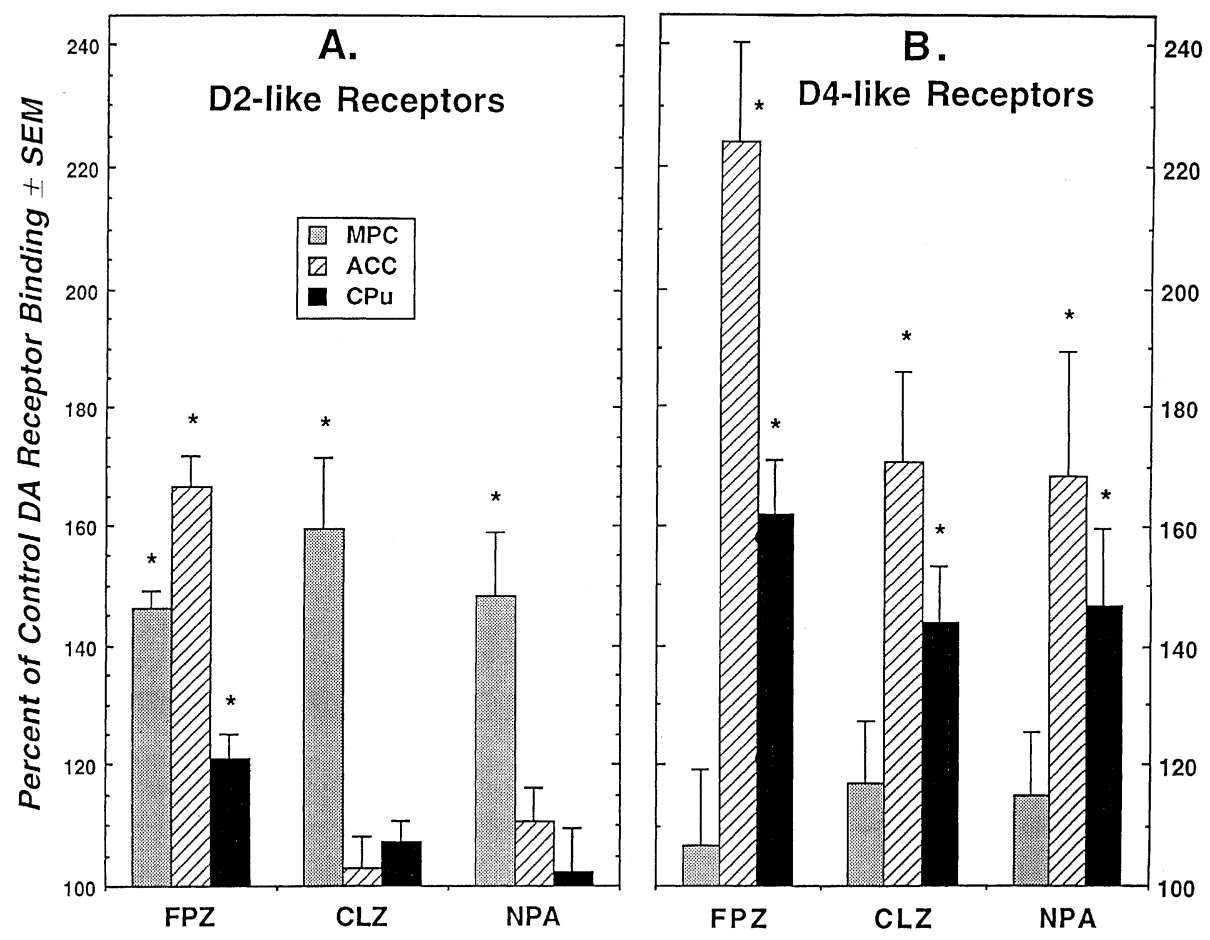

Figure 2. Percent of control DA receptor binding ( \pm SEM) after 3 weeks of daily treatment of rats with fluphenazine ( $F P Z)$, clozapine $(C L Z)$, or $\mathrm{S}( \pm)-\mathrm{N}-n$-propylnorapomorphine $(N P A)$, comparing changes in medial prefrontal cortex (MPC; shaded bars), accumbens (ACC; striped bars), and caudate-putamen ( $\mathrm{CPu}$; black bars). A. Binding of $\left[{ }^{3} \mathrm{H}\right]$ nemonapride alone (mainly to highly prevalent $\mathrm{D}_{2}$, little $\mathrm{D}_{3}$, and perhaps $\mathrm{D}_{4}$ receptors; Cf. Table 1). B. Binding of the same radioligand with unlabeled raclopride (300 $\mathrm{nM}$ ) to mask $\mathrm{D}_{2}$ and $\mathrm{D}_{3}$ sites selectively (with other masking agents to occlude sigma and 5-HT binding sites as defined in Methods) and reveal $D_{4}$ receptors more clearly (Cf. Table 5). $\left(^{*}\right)$ Indicates statistically significantly greater than in vehicle controls, as described in Methods ( $\mathrm{N}=7$ rats; $\mathrm{p}<0.05)$. 
messenger systems (Sokoloff et al. 1990; Baldessarini and Tarazi 1996).

Regarding $\mathrm{D}_{4}$ receptors, three weeks of treatment with a typical antipsychotic (fluphenazine), as well as a prototype (clozapine) and a candidate atypical antipsychotic agent $([+]-\mathrm{NPA})$, all produced consistent increases in abundance of $\mathrm{D}_{4}$-like binding in some subcortical regions of rat forebrain ( $\mathrm{CPu}$ and $\mathrm{ACC})$, but not in OT or cerebral cortex (Tables 6 and 7), in accord with results obtained with another typical neuroleptic, haloperidol (Shoots et al. 1995; Florijn et al. 1997; Tarazi et al. 1997). All three test agents used in this study have high affinity to cloned $\mathrm{D}_{4}$ receptors expressed in transfected cells ( $\mathrm{Ki}=10-60 \mathrm{nM}$ ) (Van Tol et al. 1991; Seeman and Van Tol 1993) (Table 1). Increases in $D_{4}$-like binding in $\mathrm{CPu}$ and $\mathrm{ACC}$ following all three treatments evidently reflect increased tissue density of $\mathrm{D}_{4}$ receptors (upregulation) and perhaps supersensitivity, as occurs with $D_{2}$ receptors after treatment with $D_{2}$ antagonists and other anti-DA treatments (Creese et al. 1977; Campbell et al. 1993; Baldessarini and Tarazi 1996).

Apparent increases of $\mathrm{D}_{4}$-like binding by both typical and atypical antipsychotic agents suggests that $D_{4}$ receptors may be a common site of mediation of drug antipsychotic effects. Moreover, clozapine-induced increases, and possibly supersensitivity, of $\mathrm{D}_{4}$ receptors may contribute to a high risk of psychotic exacerbation after discontinuing clozapine treatment of chronically psychotic patients (Baldessarini et al. 1997). In addition, reported elevations of $D_{4}$-like receptors in postmortem brain tissue from patients with schizophrenia (Seeman et al. 1993; Murray et al. 1995; Sumiyoshi et al. 1995) may include adaptations to antipsychotic drug exposure, although some studies failed to detect $\mathrm{D}_{4}$-like receptor upregulation in such patients (Reynolds and Mason 1994, 1995; Lahti et al. 1996). Clarification of a role of $\mathrm{D}_{4}$ receptors in the pathophysiology and treatment of psychotic disorders, and details of their regional regulation following long-term antipsychotic treatment in various species await further improvements in the assay of $\mathrm{D}_{4}$ receptor proteins, including selective radioligands or antibodies (Kebabian et al. 1997).

In conclusion, striatolimbic $\mathrm{D}_{4}$-like binding sites that appear to be accounted for mainly by $\mathrm{D}_{4}$ receptors, as well as medioprefrontal cortical $\mathrm{D}_{2}$-like receptors, may constitute attractive targets for guiding development of novel psychotropic drugs. Lower occupancy of $\mathrm{D}_{2}$ receptors in neostriatum $(\mathrm{CPu})$ by atypical antipsychotic agents may contribute to their low risk of neurological side effects. Current findings of similar long-term effects of (+)-NPA and clozapine on different $\mathrm{D}_{2}$-like DA receptor subtypes in specific regions of mammalian brain add evidence of the unique properties of such drugs and specifically encourage further consideration of $S(+)$ aporphines as potential atypical antipsychotic agents.

\section{ACKNOWLEDGMENTS}

This work was supported by NIH grants MH-34006, and MH47370, a grant from the Bruce J. Anderson Foundation, and awards from the Mailman Research Center Private Donors Neuropharmacology Research Fund (RJB), Training Grant $\mathrm{MH}-14275$ (SKY), and provision of test materials from an NIMH-RBI Chemical Synthesis Program (Contract MH30003). Drs. Peter Munson and David Rodbard of the NIH Biostatistical and Computing Center generously provided the program ALLFIT for the Macintosh microcomputer. Sandoz (clozapine) and McNeil Laboratories (haloperidol) generously donated drug substances.

\section{REFERENCES}

Baldessarini RJ (1996): Drugs and the treatment of psychiatric disorders. In Hardman JG, Limbird LE, Molinoff PB, Ruddon RW, Gilman AG (eds), Goodman and Gilman's The Pharmacologic Basis of Therapeutics. New York, McGraw-Hill, pp 399-459

Baldessarini RJ, Campbell A, Ben-Jonathan N, Ellingboe J, Zong R, Neumeyer JL (1994): Effects aporphine isomers on rat prolactin. Neurosci Lett 176:269-271

Baldessarini RJ, Frankenburg FR (1991): Clozapine-a novel antipsychotic agent. N Engl J Med 324:746-754

Baldessarini RJ, Kula NS, Campbell A, Bakthavachalam V, Yuan J, Neumeyer, JL (1992): Prolonged D antidopaminergic activity of alkylating and nonalkylating derivatives of spiperone in rat brain. Mol Pharmacol 42:856-863

Baldessarini RJ, Tarazi FI (1996): Brain dopamine receptors: a primer on their current status, basic and clinical. Harvard Rev Psychiatry 3:301-325

Baldessarini RJ, Tarazi FI, Kula NS, Gardner DM (1997): Clozapine withdrawal: Contributions of upregulated cerebral $\mathrm{D}_{4}$ receptors. Arch Gen Psychiatry (in press)

Brunello N, Masotto C, Steardo L, Markstein R, Racagni G (1995): New Insights into the biology of schizophrenia through the action mechanism of clozapine. Neuropsychopharmacology 13:177-213

Campbell A, Baldessarini RJ, Teicher MH, Neumeyer JL (1985): S(+)Apomorphines: Selective inhibition of excitatory effects of dopamine injected into the limbic system of the rat. Neuropharmacology 24:391-399

Campbell A, Baldessarini RJ, Teicher MH, Neumeyer JL (1986): Behavioral effects of apomorphine isomers in the rat: selective locomotor-inhibitory effects of $\mathrm{S}(+) \mathrm{N}-n-$ propylnorapomorphine. Psychopharmacology 88:158-164

Campbell A, Baldessarini RJ, Kula NS, Ram VJ, Neumeyer JL (1987): S(+)-methylenedioxy-N-n-propylnoraporphine: an orally active inhibitor of dopamine selective for rat limbic system. Brain Res 403:393-397

Campbell A, Baldessarini RJ, Gao Y, Ram VJ, Neumeyer JL (1990): R(-) and S(+) stereoisomers of 11-hydroxy-N-npropylnoraporphine: Central dopaminergic behavioral activity in the rat. Neuropharmacology 29:527-536

Campbell A, Yeghiayan S, Baldessarini RJ, Neumeyer JL (1991): Selective antidopaminergic effects of S(+)N-propylnoraporphines in limbic vs extrapyramidal sites in 
rat brain: Comparisons with typical and atypical antipsychotic agents. Psychopharmacology 103:323-329

Campbell A, Baldessarini RJ, Neumeyer JL (1993): Altered spontaneous behavior and sensitivity to apomorphine in rats following treatment with $\mathrm{S}(+)$-aporphines or fluphenazine. Psychopharmacology 111:351-358

Creese I, Burt DR, Snyder SH (1977): Dopamine receptor binding enhancement accompanies lesion-induced behavioral supersensitivity. Science 197:596-598

Farde L, Wiesel F-A, Stone-Elander S, Halldin C, Nordström A-L, Hall H, Sedvall G (1990): $\mathrm{D}_{2}$ dopamine receptors in neuroleptic-naive schizophrenic patients. A positron emission tomography study with $\left[{ }^{11} \mathrm{C}\right]$ raclopride. Arch Gen Psychiatry 47:213-219

Florijn WJ, Tarazi FI, Creese I (1997): Dopamine receptor subtypes: Differential regulation after eight months treatment with antipsychotic drugs. J Pharmacol Exp Ther 280:561-569

Gao Y, Zong R, Campbell A, Kula NS, Baldessarini RJ, Neumeyer JL (1988): Synthesis and dopamine agonist and antagonist effects of $\mathrm{R}(-)$ - and $\mathrm{S}(+) 11$-hydroxy-N-npropylnoraporphine. J Med Chem 31:1392-1396

Gonzalez AM, Sibley DR (1995): [ $\left.{ }^{3} \mathrm{H}\right] 7-\mathrm{OH}-\mathrm{DPAT}$ is capable of labeling dopamine $\mathrm{D}_{2}$ as well as $\mathrm{D}_{3}$ receptors. Eur J Pharmacol 272:R1-R3

Janowsky A, Neve KA, Kinze JM, Taylor B, de Paulis T, Belknap JK (1992): Extrastriatal dopamine $\mathrm{D}_{2}$ receptors: Distribution, pharmacological characterization and region-specific regulation by clozapine. J Pharmacol Exp Ther 261:1282-1290

Kebabian JW, Tarazi FI, Kula NS, Baldessarini RJ (1997): Compounds selective for dopamine receptor subtypes. Drug Discovery Today (in press)

Kula NS, Baldessarini RJ, Kebabian JW, Neumeyer JL (1994): $\mathrm{S}(+)$-Aporphines are not selective for human $\mathrm{D}_{3}$ dopamine receptors. Cell Mol Neurobiol 14:185-191

Kulagowski JJ, Broughton HB, Curtis NR, Mawer IM, Ridgill MP, Baker R, Emms F, Freedman SB, Marwood R, Patel S, Patel S, Ragan CI, Leeson PD (1996): 3-[[4-(4-Chlorophenyl)-piperazin-1-yl]-methyl]-1H-pyrrolo[2,3-b]pyridine: An antagonist with high affinity and selectivity for the human dopamine $\mathrm{D}_{4}$ receptor. J Med Chem 39:19411942

Lahti RA, Evans DL, Stratman NC, Figur LM (1993): Dopamine $\mathrm{D}_{4}$ vs. $\mathrm{D}_{2}$ receptor selectivity of dopamine receptor antagonists: Possible therapeutic implications. Eur J Pharmacol 236:483-486

Lahti RA, Roberts RC, Conley RR, Cochrane EV, Mutin A, Tamminga CA (1996): $\mathrm{D}_{2}$-type dopamine receptors in postmortem human brain sections from normal and schizophrenic subjects. NeuroReport 7:1945-1948

Lahti RA, Roberts RC, Tamminga CA (1995): $\mathrm{D}_{2}$-Family receptor distribution in human postmortem tissue: An autoradiographic study. NeuroReport 6:2505-2512

Lahti RA, Mutin A, Cochrane EV, Tepper PG, Dijkstra D, Wikstrom H, Tamminga CA (1996): Affinities and intrinsic activities of dopamine receptor agonists for the $h D_{2 L}$ and $h D_{4.4}$ receptors. Eur J Pharmacol 301:R11-R13

Levésque D, Martres M-P, Diaz J, Griffon N, Lammers CH, Sokoloff P, Schwartz J-C (1995): A paradoxical regulation of the dopamine $D_{3}$ receptor expression suggests the involvement of an anterograde factor from dopamine neurons. Proc Natl Acad Sci USA 92:1719-1723

Lidow MS, Goldman-Rakic PS (1994): A common action of clozapine, haloperidol, and remoxipride on $\mathrm{D}_{1^{-}}$and $\mathrm{D}_{2}$-dopaminergic receptors in the primate cerebral cortex. Proc Natl Acad Sci USA 91:4353-4356

Meador-Woodruff JH, Damask SP, Wang J, Haroutunian V, Davis KL, Watson SJ (1996): Dopamine receptor mRNA expression in human striatum and neocortex. Neuropsychopharmacology 15:17-29

Meador-Woodruff JH, Grandy DK, Van Tol HHM, Damask SP, Little KY, Civelli O, Watson SJ (1994): Dopamine receptor gene expression in the human medial temporal lobe. Neuropsychopharmacology 10:239-248

Meltzer HY (1991): Effects of antipsychotic drugs on serotonin receptors. Pharmacol Rev 43:587-604

Mrzljak L, Bergson C, Pappy M, Huff R, Levenson R, Goldman-Rakic PS (1996): Localization of dopamine $D_{4}$ receptors in GABAergic neurons of the primate brain. Nature 381:245-248

Murray AM, Hyde TM, Knable MB, Herman MM, Bigelow LB, Carter JM, Weinberger DR, Kleinman JE (1995): Distribution of putative $\mathrm{D}_{4}$ dopamine receptors in postmortem striatum from patients with schizophrenia. J Neurosci 15:2186-2191

Nemeroff CB, Kilts CD, Levant B, Bissette G, Campbell A, Baldessarini RJ (1991): Effects of aporphine isomers and haloperidol on regional concentrations of neurotensin in rat brain. Neuropsychopharmacology 4:27-33

Neve KA, Neve RL (1997): The Dopamine Receptors. Totowa, NJ, Humana Press

Paxinos F, Watson C (1982): The Rat Brain in Stereotaxic Coordinates. New York, Academic Press

Reynolds GP, Mason SL (1994): Are striatal dopamine $\mathrm{D}_{4}$ receptors increased in schizophrenia? J Neurochem 63:157-1577

Reynolds GP, Mason SL (1995): Absence of detectable striatal dopamine $\mathrm{D}_{4}$ receptors in drug-treated schizophrenia. Eur J Pharmacol 281:R5-R6

Roth BL, Tandra S, Burgess LH, Sibley DR, Meltzer HY (1995): $\mathrm{D}_{4}$ dopamine receptor affinity does not distinguish between typical and atypical antipsychotic drugs. Psychopharmacology 120:365-368

Schoots O, Seeman P, Guan HC, Paterson AD, Van Tol HHM (1995): Long-term haloperidol elevates dopamine $\mathrm{D}_{4}$ receptors by 2-fold in rats. Eur J Pharmacol 289:67-72

Seeman P, Guan H-C, Van Tol HHM (1993): Dopamine $D_{4}$ receptors elevated in schizophrenia. Nature 365:441-445

Seeman P, Guan H-C, Van Tol HHM (1995): Schizophrenia: Elevation of dopamine $\mathrm{D}_{4}$-like sites, using $\left[{ }^{3} \mathrm{H}\right]$ nemonapride and [ $\left.{ }^{125} \mathrm{I}\right]$ epidepride. Eur J Pharmacol 286:R3-R5

Seeman P, Van Tol HHM (1993): Dopamine $D_{4}$ receptors bind inactive $(+)$-aporphines, suggesting neuroleptic role; Sulpiride not stereoselective. Eur J Pharmacol 233:173-174

Sokoloff P, Giros B, Martres M-P, Bouthenet M-L, Schwartz J-C (1990): Molecular cloning and characterization of a novel dopamine receptor: $\mathrm{D}_{3}$ as a target for neuroleptics. Nature 347:146-151 
Sumiyoshi T, Stockmeier CA, Overholser JC, Thompson PA, Meltzer HY (1995): Dopamine $\mathrm{D}_{4}$ receptors and effects of guanine nucleotides on $\left[{ }^{3} \mathrm{H}\right]$ raclopride binding in postmortem caudate nucleus of subjects with schizophrenia or major depression. Brain Res 681:109-116

Suzuki T, Kobayashi K, Nagatsu T (1995): Genomic structure and tissue distribution of the mouse dopamine $\mathrm{D}_{4}$ receptor. Neurosci Lett 199:69-72

Tarazi FI, Florijn WJ, Creese I (1997): Differential regulation of dopamine receptors following chronic typical and atypical antipsychotic drug treatment. Neuroscience 78:985-996

Tarazi FI, Campbell A, Yeghiayan SK, Baldessarini RJ (1997): Localization of dopamine receptor subtypes in corpus striatum and nucleus accumbens septi of rat brain:
Comparison of $\mathrm{D}_{1^{-}}, \mathrm{D}_{2^{-}}$, and $\mathrm{D}_{4}$-like receptors. Neuroscience (in press)

Van Tol HHM, Bunzow JR, Guan H-C, Sunahara RK, Seeman P, Niznik HB, Civelli O (1991): Cloning of a human dopamine $\mathrm{D}_{4}$ receptor gene with high affinity for the antipsychotic clozapine. Nature 350:614-619

Wallace DR, Booze RM (1995): Identification of $D_{3}$ receptors in the rat striatum and nucleus accumbens using ( \pm )-7hydroxy- $N, N-$ di- $n-\left[{ }^{3} \mathrm{H}\right]$ propyl-2-aminotetralin and carbetapentane. J Neurochem 64:700-710

Wong DF, Wagner HN Jr, Tun LE, Dannals RF, Pearlson GD, Links JM, Tamminga CA, Broussolle EP, Ravert HT, Wilson AA, Toung JKT, Malat J, Williams JA, O'Tuama LA, Snyder SH, Kuhar MJ, Gjedde A (1986): Positron emission tomography reveals elevated $\mathrm{D}_{2}$ dopamine receptors in drug-naive schizophrenics. Science 234: 1558-1563 